\title{
Trifolium pratense: A New Activator of Purine Degradation
}

\author{
Hikmet Can Çubukçư ${ }^{1 *}$, Nazlı Seda Kılıçaslan² ${ }^{2}$ and İlker Durak ${ }^{1}$ \\ ${ }^{1}$ Department of Medical Biochemistry, Ankara University Faculty of Medicine, Turkey \\ ${ }^{2}$ Department of Field Crops, Medicinal and Aromatic Plants, Ankara University Faculty of Agriculture, Turkey
}

Submission: August 17, 2018; Published: October 11, 2018

*Corresponding author: Hikmet Can Çubukçu, Department of Medical Biochemistry, Ankara University Faculty of Medicine, Turkey,

Email: hikmetcancubukcu@gmail.com

\section{Abstract}

Trifolium pratense is known to have antioxidant, anti-inflammatory, antilipidemic, hepatoprotective and anticarcinogenic effects. The purpose of this investigation is to investigate the possible effects of Trifolium pratense on purine degradation rate.

Adenosine degradation in the biological tissue was monitored by analyzing uric acid levels. While $27.27 \%$ increase at uric acid levels was determined in control samples, 130,05 \% increases were found for extract-treated samples.

The research has shown that Trifolium pratense may exhibit anticarcinogenic activity by causing purine degradation.

Keywords: Trifolium pratense; Radiotherapy and chemotherapy, Natural remedies; Anticarcinogenic; Antioxidant, Anti-inflammatory, Antilipidemic, Hepatoprotective

\section{Introduction}

Cancer takes an attention as a worldwide health problem [1]. In addition to radiotherapy and chemotherapy, natural remedies draw attention to cancer treatment [2].

Trifolium pratense is known to have antioxidant, anti-inflammatory, antilipidemic, hepatoprotective and anticarcinogenic effects due to its active substances like Taxifolin and quercetin [3]. It is also used for reducing menopausal symptoms like hot flushes [4].

Purines and pyrimidines are precursors of DNA synthesis. Adenosine is a purine nucleoside which also plays a role in energy transfer and signal transduction. Nucleotides are synthesized in both de novo and salvage pathways. Products released after nucleic acid and nucleotide cofactor catabolism constitutes purine bases which are used in nucleotide synthesis at salvage pathways [5]. Degradation of these precursors by other factors can deplete nucleotide pool and decrease DNA synthesis.

We aimed to investigate possible effects of Trifolium pratense on purine degradation rate. For this purpose, adenosine degradation in the biological tissue was monitored by analyzing uric acid levels during incubation.

\section{Material and Method}

\section{Preparation of samples}

Fresh cattle liver was obtained from a local slaughterhouse. Liver tissues were stored at $-80^{\circ} \mathrm{C}$ till analysis. Before the assays, liver tissue was homogenized by DIAX 900 (Heidolph, Germany) in saline solution ( $\% 10 \mathrm{w} / \mathrm{v}$ ). Then, the homogenates were centrifuged at $3000 \mathrm{rpm}$ for 20 minutes by Harrier 18/80 centrifuge (MSE, London, UK). The clear supernatant fraction of liver homogenate was then separated and used in the assays.

Aqueous extract of Trifolium pratense was prepared at the concentration of $\% 10(\mathrm{w} / \mathrm{v})$ with distilled water.

Adenosine solution was prepared at a concentration of $0,5 \mathrm{mM}$.

\section{Experiment protocol}

Adenosine solution $(0,1 \mathrm{~mL})$ was added into $1 \mathrm{~mL}$ supernatant fraction of liver homogenate. Then, $0,5 \mathrm{~mL}$ aqueous extract of Trifolium pratense was added into the mixture. For control samples, $0,5 \mathrm{~mL}$ distilled water was used instead of an aqueous extract of Trifolium pratense. Mixtures of the control and treated 
samples were analyzed for uric acid determination immediately and after 20 hours of incubation at $37^{\circ} \mathrm{C}$. Modified alkaline phosphotungstate method was utilized for determination of uric acid concentration [6]. Absorbances were measured spectrophotometrically by using Helios alpha Ultraviolet/Visible Spectrophotometer (Unicam, Cambridge, UK).

\section{Results}

Preincubation and postincubation uric acid levels were compared by using paired sample T-test. After incubation, statistically significant differences were found for both control and treated samples (Table 1). While $27.27 \%$ increase at uric acid levels was determined in control samples, 130,05\% increases were found for extract-treated samples. The differences were found statistically significant (Table 1).

Table 1: Comparison of preincubation and postincubation uric acid levels.

\begin{tabular}{|c|c|c|c|}
\hline & Control & $\begin{array}{c}\text { Treated } \\
\text { Sample }\end{array}$ & p value \\
\hline $\begin{array}{c}\text { Preincubation } \\
\text { mean (mg/dL) }\end{array}$ & 0,594 & 0,594 & $<0,001^{\text {a }}$ \\
\hline $\begin{array}{c}\text { Postincubation } \\
\text { mean (mg/dL) }\end{array}$ & 0,756 & 1,367 & $<0,001^{\text {a }}$ \\
\hline $\begin{array}{c}\text { Mean } \\
\text { Diferences } \\
\text { (mg/dL) }\end{array}$ & 0,162 & 0,773 & $<0,001^{\text {b }}$ \\
\hline $\begin{array}{c}\text { Percentage } \\
\text { Increase (\%) }\end{array}$ & 27,27 & 130,05 & \\
\hline
\end{tabular}

a:Paired Sample T Test , b: Independent Sample T Test.

\section{Discussion}

Trifolium pratense contains a high amount of polyphenolic substances which exhibit antioxidant effects. Most widely studied feature of Trifolium pratense is its estrogenic effects and usage in postmenopausal women $[7,8]$.

There is insufficient knowledge about anticarcinogenic activities of Trifolium pratense in literature. Jarred et al [9] showed that Trifolium pratense-derived dietary isoflavones led to apoptosis in prostate carcinoma tissue [9].

In our study, we investigated adenosine degradation by analyzing uric acid levels before and after incubation. Uric acid levels were increased significantly in both treated and control samples. While \%27 increase at uric acid levels was detected for control samples, \%130 increase was determined for samples treated with Trifolium pratense as summarized in (Table 1). These results suggest that Trifolium pratense activate adenosine degradation.

It is known that purine and pyrimidine bases are utilized in nucleotide synthesis at salvage pathways [5]. Degradation of these precursors can inhibit DNA synthesis in owing to substrate deficiency in the enzymatic process. Cell generation may halt due to DNA synthesis reduction. Rapid propagation of cancerous tissues can be decreased by inhibiting DNA synthesis. Trifolium pratense may exhibit anticarcinogenic activity by causing purine degradation. Further studies are required to establish possible anti-carcinogenic effects of Trifolium pratense.

\section{References}

1. Ferlay J, Soerjomataram I, Dikshit R, Eser S, Mathers C, et al. (2015) Cancer incidence and mortality worldwide: sources, methods and major patterns in GLOBOCAN 2012. Int J Cancer 136(5): E359-E386.

2. Tavakoli J, Miar S, Majid Zadehzare M, Akbari H (2012) Evaluation of Effectiveness of Herbal Medication in Cancer Care: A Review Study. Iran J Cancer Prev 5(3): 144-156.

3. Ç̈̈lgeçen H, Koca U, Büyükkartal HN (2011) Chapter 115 - Use of Red Clover (Trifolium pratense L.) Seeds in Human Therapeutics. In: Preedy VR, Watson RR, Patel VB (Eds.), Nuts and Seeds in Health and Disease Prevention. Academic Press, San Diego, California p. 975-980.

4. Myers SP, Vigar V (2017) Effects of a standardised extract of Trifolium pratense (Promensil) at a dosage of $80 \mathrm{mg}$ in the treatment of menopausal hot flushes: A systematic review and meta-analysis. Phytomedicine 24: 141-147.

5. Moffatt BA, Ashihara H (2002) Purine and Pyrimidine Nucleotide Synthesis and Metabolism. Arabidopsis Book 1: e0018.

6. Henry RJ, Sobel C, Kim J (1957) A modified carbonate-phosphotungstate method for the determination of uric acid and comparison with the spectrophotometric uricase method. Am J Clin Pathol 28(2): 152-160.

7. Beck V, Rohr U, Jungbauer A (2005) Phytoestrogens derived from red clover: An alternative to estrogen replacement therapy? The Journal of Steroid Biochemistry and Molecular Biology 94(5): 499-518.

8. Lipovac M, Chedraui P, Gruenhut C, Gocan A, Stammler M, et al. (2010) Improvement of postmenopausal depressive and anxiety symptoms after treatment with isoflavones derived from red clover extracts. Maturitas 65(3): 258-261.

9. Jarred RA, Keikha M, Dowling C, McPherson SJ, Clare AM, et al. (2002) Induction of apoptosis in low to moderate-grade human prostate carcinoma by red clover-derived dietary isoflavones. Cancer Epidemiol Biomarkers Prev 11(12): 1689-1696. 
This work is licensed under Creative Commons Attribution 4.0 License

DOI: 10.19080/JTMP.2018.03.555616

\section{Your next submission with Juniper Publishers} will reach you the below assets

- Quality Editorial service

- Swift Peer Review

- Reprints availability

- E-prints Service

- Manuscript Podcast for convenient understanding

- Global attainment for your research

- Manuscript accessibility in different formats ( Pdf, E-pub, Full Text, Audio)

- Unceasing customer service

Track the below URL for one-step submission https://juniperpublishers.com/online-submission.php 